\title{
The Circular Carbon Economy Index - Methodological Approach and Conceptual Framework
}

Mari Luomi, Fatih Yilmaz, Thamir Alshehri and Nicholas Howarth 


\section{About KAPSARC}

The King Abdullah Petroleum Studies and Research Center (KAPSARC) is a non-profit global institution dedicated to independent research into energy economics, policy, technology and the environment across all types of energy. KAPSARC's mandate is to advance the understanding of energy challenges and opportunities facing the world today and tomorrow, through unbiased, independent, and high-caliber research for the benefit of society. KAPSARC is located in Riyadh, Saudi Arabia.

This publication is also available in Arabic.

\section{Legal Notice}

(C) Copyright 2021 King Abdullah Petroleum Studies and Research Center ("KAPSARC"). This Document (and any information, data or materials contained therein) (the "Document") shall not be used without the proper attribution to KAPSARC. The Document shall not be reproduced, in whole or in part, without the written permission of KAPSARC. KAPSARC makes no warranty, representation or undertaking whether expressed or implied, nor does it assume any legal liability, whether direct or indirect, or responsibility for the accuracy, completeness, or usefulness of any information that is contained in the Document. Nothing in the Document constitutes or shall be implied to constitute advice, recommendation or option. The views and opinions expressed in this publication are those of the authors and do not necessarily reflect the official views or position of KAPSARC. 


\section{Summary}

he circular carbon economy (CCE) approach, developed during Saudi Arabia's G20 Presidency and endorsed by G20 leaders and energy ministers, can be used as a framework for holistic assessments of all available energy and emission management technologies within the confines of a global carbon budget. KAPSARC's Circular Carbon Economy Index project, launched in 2021, will develop a composite indicator (index) that measures and tracks country performance and potential on various dimensions of the CCE to support related policy discussions and planning.

This paper describes best practices in methodological approaches to constructing composite indicators, develops a conceptual framework for the CCE Index and puts forward an initial selection of indicators. The paper is intended to serve as a first step in the construction of the initial edition of the CCE Index in 2021, which will capture a consensus on the various choices needed for a robust index on the basis of a series of expert and stakeholder consultations.

The paper is divided into four sections. The first briefly introduces the CCE concept and explains the role of metrics in helping to operationalize it as a policy tool. The second section makes the case for the CCE index by surveying existing composite indicators that measure CCE-related concepts in the context of country performance and pointing out a gap in this regard. The third section provides a 'deconstruction' of the concept. Based on this and an examination of various existing CCE-relevant indicators, it puts forward a conceptual framework for the CCE Index and an initial list of suggested indicators for use in stakeholder consultations in 2021. The concluding section identifies the best practice in developing composite indicators and provides a process description. It also describes the next steps in developing the index. 
The circular carbon economy (CCE) concept can be understood as a policy tool that enables holistic assessments of all available energy and emission management technologies within the confines of a set carbon budget. The CCE can support the evaluation of different policy options and help design net-zero emission pathways adapted to countries' national circumstances, resource endowments and competitive advantages. The CCE can also serve as a tool to measure how countries are progressing toward circular, net-zero emission economies in which atmospheric or 'fugitive carbon' emissions are avoided through reducing, recycling, reusing and removing carbon dioxide $\left(\mathrm{CO}_{2}\right)$ and other greenhouse gas (GHG) emissions.

\section{Emergence of CCE}

The CCE is a recent concept. It was originally envisaged by William McDonough (2016) as an extension of the industrial ecology concept of the circular economy. While the circular economy focuses on material flows, CCE is exclusively focused on energy and $\mathrm{CO}_{2}$ or $\mathrm{GHG}$ emissions. In recent years, scholars and policymakers in various countries have taken an interest in the CCE concept, applying it to a range of contexts, including proposals to substitute oil imports with domestic waste and coal as a feedstock for the chemical industry in Germany, or catalyze the development of technologies that help generate value from reducing or using atmospheric $\mathrm{CO}_{2}$ in the United States (Alshehri et al. n.d).

The concept gained prominence during Saudi Arabia's G20 Presidency, with its endorsement by the group's energy ministers and leaders (G20 Energy Ministers 2020; G20 Saudi Arabia 2020). Through the year, several Saudi-based actors promoted the concept as a lens or framework for emissions management that takes a holistic view on emissions reduction technologies, focuses on minimizing $\mathrm{CO}_{2}$ emissions rather than reducing the use of hydrocarbons, and recognizes the economic value of carbon. From this perspective, they have highlighted the CCE as an approach that allows for:

- Exploring pathways to carbon neutrality that incorporate all low and net-zero emissions technologies and help identify the most appropriate options for each country's context.

- Integrating renewable energy, energy efficiency and non-renewable energy policies to maximize energy systems' potential for emission reductions.

- Recognizing that a transition to renewable energy sources may not be fast enough from a climate change mitigation perspective. Many scenarios suggest that pathways incorporating hydrocarbons with carbon capture and storage (CCS) into the mix can be more cost-efficient, both globally and in many countries.

- Drawing attention to existing and potential future bottlenecks that might prevent countries or the world from reaching net-zero emissions, including relating to the pace of CCS or hydrogen scale-up, or mitigating emissions in hard-to-abate sectors (such as heavy industries and heavy-duty, air and maritime transport).

- Exploring a broader range of carbon capture utilization and storage (CCUS)-related mitigation options for countries with large, vertically integrated, hydrocarbon sectors. This includes economic instruments that go beyond pricing carbon as an externality and put a value on carbon, including through CCS (AI Saud and AI Shalan 2020; Heidug and Zakkour 2019; IEF 2020; KAPSARC 2020; Williams 2019). 


\section{The need for common metrics}

The CCE can be used as a systems-oriented climate change mitigation framework - either at the national or global level. It can be used to measure the gap between current emissions and net-zero emissions, to create technology-specific pathways and enabling policies to support the transition to carbon neutrality. Operationalizing the CCE into a policy tool, however, requires conceptual clarity and a general agreement on its aims and metrics.

Saudi-affiliated scholars and stakeholders have used a definition of CCE that builds on the circular economy's three dimensions - reducing, reusing and recycling - and adds carbon storage as a fourth R, namely 'remove' (Williams 2019). However, different authors and actors have made different choices when classifying types of $\mathrm{CO}_{2}$ flows (e.g., KAPSARC [2020]; AI Saud and AI Shalan [2020]; KAUST [2021]).

The lack of agreement on the conceptual definition of a concept does not necessarily hinder its use. 'Sustainable development' is an example of a concept that continues to be used widely without an agreed definition. Conceptual clarity, however, is crucial when developing metrics to support policymaking toward an agreed goal or conceptual ideal. Metrics can help countries assess where they stand regarding the goal/ideal, and metrics can help identify gaps and potential for future progress. The United Nations (UN) Sustainable Development Goals (SDGs) from 2015 is a framework built around 17 universal goals and 169 related targets. Progress on each goal and indicator is evaluated through 231 unique, commonly agreed indicators (UNSTATS 2021).

A CCE index can help illustrate how the CCE concept can work in practice, track countries' progress on implementing its key dimensions and promote engagement between stakeholders and countries on the concept. Such an index can help assess the following questions:

- How can the elements of the CCE concept be tracked quantitatively to enable a comparison between countries?

- What are the areas in which substantial progress is being made toward carbon circularity and net-zero emissions, and where are the main opportunities for future progress?

- How can fossil fuel use be made consistent with a net-zero emissions world?

- Where are the main opportunities for sharing experiences and policy learning?

\section{Purpose and structure of the paper}

This methodology paper puts forward a conceptual framework for the CCE that enables quantifying its various dimensions for use in policy discussions and to inform policymaking. This conceptual framework is the first step in the construction of the initial edition of the CCE Index in 2021, which will capture a consensus on the various choices needed for a robust index based on a series of expert and stakeholder consultations.

The end goal of this exercise is an index, formally known as a composite indicator, that uses a set of quantitative indicators to measure and compare country performance and enabling environments on key dimensions of the CCE. Indices are compilations of multiple individual indicators underpinned by a model. They are particularly useful for measuring complex and multidimensional concepts and for related benchmarking. 
Beyond the metrics, the CCE Index also has a further purpose. It is intended as a vehicle to promote an understanding of the CCE concept and discussions around holistic approaches for managing emissions across energy systems and economies, and understanding gaps in policies that need addressing. It comprises two parts - one sub-index for assessing current performance and another sub-index for measuring the potential for progress based on a variety of enabling factors. In recognition of the fact that fossil fuel producing countries often share specific characteristics (large hydrocarbon endowments, path dependencies associated with fossil fuel industries and specific technology options and challenges relating to reaching carbon circularity), the authors will also explore the inclusion of a set of specific indicators (or a 'lens') that can be applied to oil-producing countries included in the index.
The remainder of this paper is divided into three sections: the next section provides a technical discussion of composite indicators and their use in measuring CCE-related concepts in the context of country performance. The following section provides a 'deconstruction' of the concept of CCE, and, based on this and an examination of various existing CCE-relevant indicators, presents a conceptual framework for the CCE Index and an initial list of suggested indicators, for use in stakeholder consultations in 2021. The concluding section identifies the best practice in developing composite indicators, provides a process description, and describes the next steps. 


\section{Composite Indicators and the Case for a CCE Index}

D espite the existence of a high and growing number of composite indicators, no single existing index appears to fully capture how the CCE approaches mitigation and net-zero emissions. As a concept, the CCE is most closely related to that of the circular economy. ${ }^{1}$ It also shares features with the concepts of the green economy and sustainable production and consumption (Alshehri et al. n.d.). Like these concepts, CCE is multidimensional: it cannot be meaningfully measured with a single indicator. While measuring a country's total GHG emissions at any given time provides important information, it does not indicate what policies and technologies the country is employing to have reached a given level, nor does it serve to provide information about the country's potential to reduce emissions.

This section provides an overview of the benefits and challenges relating to the use of composite indicators in the country context. It provides examples of CCE-relevant indices that guide the design of the CCE Index.

\section{Composite indicators}

Composite indicators, usually called indices, are a common method for measuring multidimensional concepts. They are composed of individual indicators and based on an underlying model (OECD 2008; UNECE 2019). For countries (as opposed to companies, for example), composite indicators are used to examine trends, draw attention to issues, set policy priorities, clarify and quantify policy objectives, assist in forecasting trends, monitor policy implementation and impact, and benchmark country performance (Eurostat 2017b).

The advantages and challenges associated with composite indicators are well known. Indices can provide easily interpretable measures of complex issues for policymaking and enable the assessment of countries' progress over time and relative to one another. They can also be used as communication tools vis-à-vis non-specialist audiences. On the flip side, if poorly constructed, composite indicators can send misleading or partial messages that lead to simplistic and misinformed policy decisions. Composite indicators may also carry the risk of being misused, for example to support specific policy preferences, which is why clear and transparent conceptual frames and methods are crucial. Since they are aggregate measures, high-level index results may also hide shortcomings in important areas if they are poorly communicated or interpreted. The same could happen if relevant data underpinning an index is underreported or deliberately not made available (OECD 2008; Eurostat 2017b).

However, if constructed in a robust and transparent way, and understood as efforts to use the best available knowledge and data to stimulate further policy discussions and studies, composite indicators can be valuable tools.

\section{CCE-related indices}

Hundreds of composite indicators have been developed to date, and several are used by governments and other actors worldwide to support or influence policymaking. Some of the best-known indices date back two or three decades, including the UN Development Programme's (UNDP's) Human Development Index (HDI) (1990), the World Economic Forum's Global Competitiveness Index (1999), the World Wildlife Fund's Ecological Footprint measure (2000), and Yale and Columbia Universities' Environmental Sustainability/ Performance Index (ESI/EPI) (2000). 
Many composite indicators have emerged in response to a perceived gap in existing tools used to measure various dimensions of development, such as well-being, resilience or sustainability. The HDI, for example, was developed as a critique of gross domestic product (GDP) (when used as the sole metric of development) and emphasizes health and education as higher values in human life than "the market value of commodities bought and sold"
(Amartya Sen in UNDP [2020], xi). The creators of the EPI aspired to develop a single, GDP-type indicator for environmental sustainability, and the authors of the Ecological Footprint sought to factor in environmental externalities of development and highlight the Earth's system limits (SEDAC 2020). Table 1 lists a selection of CCE-relevant indices and their characteristics.

Table 1. CCE-relevant country-level composite indicators.

\section{Focus and purpose}

Sustainable development

Human Development Index (UNDP)

\section{Environmental Performance Index (Yale University and Columbia University)}

Emphasizes that people and their capabilities should be the ultimate criteria for assessing the development of a country, not economic growth alone.

Developed as the Environmental Sustainability Index until 2015, the EPI summarizes the state of countries' environmental health and ecosystem vitality.

\section{Sustainable Development}

Goals Index and Dashboards

(UN Sustainable

Development Solutions

Network [SDSN])
Provides a summary of countries' current performance and trends in relation to achieving the 17 SDGs. SDSN and partners also publish regional and subnational indices.
Characteristics (dimensions, indicators, coverage)

Based on three dimensions: long and healthy life, knowledge and a decent standard of living. Covers 189 countries.

Uses 32 performance indicators across 11 categories. Measures performance in relation to common environmental challenges and established policy targets. Covers 180 countries.

Uses an evolving basket of $\sim 80$ indicators ( 100 for OECD countries) to assess the performance and trends at the indicator, goal and overall levels. Covers 160-170 countries.

\section{Energy sustainability}

Energy Trilemma Index (World Energy Council)

\section{Energy Transition Index} (World Economic Forum)
Provides a score of country performance in achieving a sustainable mix of energy policies, or how well countries manage the trade-offs of the 'trilemma.'

Measures countries' energy system performance and energy transition readiness.
Regulatory Indicators for Sustainable Energy (World Bank and the Energy Sector Management Assistance Program [ESMAP])

Carbon Capture and Storage Readiness Index (Global CCS Institute)
Seeks to measure how policies and regulations, specifically the strength and breadth of government support and actions taken, support the three dimensions of SDG 7.

Identifies countries that are leading in creating enabling environments for the commercial deployment of CCS.
Based on three dimensions: energy security, energy equity (accessibility and affordability) and environmental sustainability. Covers 108 countries.

Consists of a two-part framework: three "system performance imperatives" (access and security, sustainability, and growth) and six "transition readiness enabling dimensions." Based on 40 indicators. Covers 115 countries. Based on three pillars - energy access, energy efficiency and renewable energy - and measured by 27 indicators, 80 sub-indicators, 158 questions and 3,000 documents. Covers 111 countries.

Measures progress through four indicators that constitute barriers or accelerators to CCS deployment: inherent interest, legal and regulatory frameworks, policy developments, and storage development. Covers $30+$ countries. 


\begin{tabular}{|c|c|c|}
\hline \multicolumn{3}{|l|}{ Climate change } \\
\hline $\begin{array}{l}\text { Climate Change Performance } \\
\text { Index (Germanwatch, Climate } \\
\text { Action Network International } \\
\text { and New Climate Institute) }\end{array}$ & $\begin{array}{l}\text { Tracks countries' efforts to combat climate } \\
\text { change in order to enhance international } \\
\text { transparency. }\end{array}$ & $\begin{array}{l}\text { Assesses performance under four categories: } \\
\text { GHG emissions, renewable energy, energy } \\
\text { use and climate policy through } 14 \text { indicators. } \\
\text { Covers } 57 \text { countries and the European Union } \\
\text { (EU). }\end{array}$ \\
\hline $\begin{array}{l}\text { Change Readiness Index } \\
\text { (KPMG) }\end{array}$ & $\begin{array}{l}\text { Assesses countries' abilities to manage } \\
\text { change. Focuses specifically on the SDGs and } \\
\text { a 'climate-ready future.' }\end{array}$ & $\begin{array}{l}\text { Structured around three pillars of capability: } \\
\text { government, enterprise, and people and } \\
\text { society. Contains } 150 \text { variables. Covers } 140 \\
\text { countries. }\end{array}$ \\
\hline \multicolumn{3}{|l|}{ Circular economy } \\
\hline $\begin{array}{l}\text { EU Circular Economy } \\
\text { Monitoring Framework } \\
\text { (European Commission) }\end{array}$ & $\begin{array}{l}\text { Aims to measure progress in and assess the } \\
\text { effectiveness of action in moving toward the } \\
\text { circular economy in the EU and its member } \\
\text { states. }\end{array}$ & $\begin{array}{l}\text { Consists of } 10 \text { indicators covering four } \\
\text { thematic areas: production and consumption, } \\
\text { waste management, secondary raw materials, } \\
\text { and competitiveness and innovation. Covers } \\
\text { the EU member states. }\end{array}$ \\
\hline \multicolumn{3}{|c|}{ Economy, enabling environments, innovation, knowledge and technology } \\
\hline $\begin{array}{l}\text { Global Competitiveness } \\
\text { Index (World Economic } \\
\text { Forum) }\end{array}$ & $\begin{array}{l}\text { Measures national competitiveness, defined as } \\
\text { the set of institutions, policies and factors that } \\
\text { determine the level of productivity. }\end{array}$ & $\begin{array}{l}\text { Based on a framework organized into two } \\
\text { sub-indices (innovation input and innovation } \\
\text { output), and } 103 \text { indicators distributed across } \\
12 \text { pillars ('drivers of productivity'). Covers } 141 \\
\text { countries. }\end{array}$ \\
\hline $\begin{array}{l}\text { Ease of Doing Business } \\
\text { Score (World Bank) }\end{array}$ & $\begin{array}{l}\text { Benchmarks economies in relation } \\
\text { to regulatory best practice for local } \\
\text { entrepreneurs. }\end{array}$ & $\begin{array}{l}\text { Covers } 10 \text { topics (e.g., starting a business, } \\
\text { registering property, getting credit, paying } \\
\text { taxes) and includes } 41 \text { indicators. Covers } 190 \\
\text { countries. }\end{array}$ \\
\hline $\begin{array}{l}\text { Global Innovation Index } \\
\text { (Cornell University, INSEAD } \\
\text { and World Intellectual } \\
\text { Property Organization } \\
\text { [WIPO]) }\end{array}$ & $\begin{array}{l}\text { Measures countries' innovation performance } \\
\text { based on a broad vision of innovation, } \\
\text { including political environment, education, } \\
\text { infrastructure and business sophistication. }\end{array}$ & $\begin{array}{l}\text { Comprises two sub-indices: innovation input, } \\
\text { innovation output. Based on seven themes } \\
\text { (e.g., institutions, business sophistication, and } \\
\text { knowledge and technology outputs) and } 80 \\
\text { indicators. Covers } 131 \text { countries. }\end{array}$ \\
\hline $\begin{array}{l}\text { Global Knowledge Index } \\
\text { (UNDP and Mohammed } \\
\text { Bin Rashid Al Maktoum } \\
\text { Knowledge Foundation) }\end{array}$ & $\begin{array}{l}\text { Measures 'knowledge' through its } \\
\text { constituent components and the general } \\
\text { enabling environment. Seeks to provide a } \\
\text { comprehensive approach to 'knowledge-based } \\
\text { development.' }\end{array}$ & $\begin{array}{l}\text { Covers six thematic areas and the general } \\
\text { enabling environment. Includes } \sim 150 \text { variables. } \\
\text { Covers } 136 \text { countries. }\end{array}$ \\
\hline
\end{tabular}

Sources: Authors, based on official composite indicator documentation, accessed December 2020.

Because of the CCE's recent origins, there are no publicly available composite indicators specifically dedicated to the concept; this is based on a survey by the authors. There is a dearth of even circular economy-related performance or readiness assessment tools applicable to the country-level, despite the concept's rising popularity since the 2000s (one study counted 114 circular economy definitions [Kircherr et al. 2017]). The European Union's (EU's) monitoring framework is the only major country-level quantification attempt in this area. ${ }^{2}$ However, in the areas of energy sustainability and climate change policy (see Table 1), which are closely related to the CCE, there are growing efforts to assess country performance. For a discussion on the specific characteristics of socioeconomic indices, see Appendix 1. 


\section{Conceptual Framework for the CCE Index}

o construct an index that measures CCE in a country context, a high-level definition of the CCE and its ultimate goals is essential.

For the purposes of the CCE Index, CCE is defined as an approach to managing $\mathrm{CO}_{2}$ (and other $\mathrm{GHG}$ ) emissions, including ultimately achieving net-zero emissions, that considers all available mitigation options and helps identify gaps in implementation, policy and enabling environments. Consequently, the Index is intended to support climate change and energy policymakers and stakeholders in designing policies aimed at achieving net-zero emissions, or 'carbon circularity,' by mid-century or soon thereafter.

The CCE Index will provide a quantitative evaluation of two dimensions of relevance to CCE: countries' current performance and future potential, in the form of two sub-indices. Present-day performance is important for establishing where countries stand at the moment, but measuring whether countries have the enablers to progress toward carbon circularity is equally important. The Index may also include a set of additional indicators for oil producers (countries and companies) that measure both performance and enablers. These could be applied as a lens on top of, or be examined separately to, the two main sub-indices. This 'lens' would only be applied when evaluating and comparing oil producers.

This section explains the process for defining the dimensions, or sub-indices, of the CCE Index and elaborates on the relationships between the dimensions and the components/indicators under each dimension. Fundamental assumptions relating to the conceptual framework are also discussed in this section.
It is initially assumed that the first edition of the CCE Index will include the 19 member countries of the G20, as well as 20 leading oil-producing countries. For this latter group, an emphasis of the CCE on carbon utilization and storage technologies is particularly relevant, ${ }^{3}$ and certain related industry-specific metrics could allow for more meaningful comparisons.

\section{Deconstructing CCE}

There are important differences in how authors and actors have defined the CCE's main categories. McDonough's (2016) major contribution to the concept of the CCE was his classification of carbon into three categories - living, durable and fugitive and the notion that only fugitive carbon is a problem (McDonough 2016, 349). He also put forward three carbon 'management strategies': positive, neutral and negative (McDonough 2016, 350). Since 2019, several Saudi Arabia-based authors, including Williams (2019), KAPSARC (2020), AI Saud and AI Shalan (2020) and McDonough himself (2020), have used a classification of CCE carbon management strategies that builds on the three Rs of the circular economy (reduce, reuse and recycle) and adds a fourth R (remove). Through 2020, the CCE also featured in several G20 documents, and international energy organizations contributed to a series of KAPSARC-coordinated CCE guides, each focused on one 'R.' One G20 Presidency report focused specifically on how climate change adaptation can contribute to mitigation and the CCE (G20 Climate Stewardship Working Group 2020a). These CCE 'taxonomies' are summarized in Table 2. 
Table 2. Various ways to deconstruct the CCE.

McDonough (2016)

\section{Living carbon}

Organic carbon that flows through biological cycles.

\section{Carbon positive (management)}

Releasing GHG emissions into the atmosphere or plastic waste into the ocean.

\section{Durable carbon}

Carbon locked in stable form ranging from coal and limestone to recyclable polymers and fiber to building materials.

\section{Carbon neutral (management)}

Either actions that transform or maintain durable carbon or that do not release carbon, such as renewable energy.

\section{Fugitive carbon}

Anthropogenic GHG emissions from fossil fuel combustion, deforestation, agriculture etc., and marine plastics.

\section{Carbon negative (management)}

Either converting atmospheric carbon or durable carbon, e.g., compostable polymers, into living carbon, or atmospheric carbon into durable carbon, e.g., polymers or building materials.

KAPSARC CCE guides, including an overview by Williams (2020)

\section{Reduce}

Minimizing fugitive carbon by employing energy efficiency, non-bio renewable energy, nuclear energy and fuel switching.

\section{Recycle}

Minimizing fugitive carbon by encouraging mitigation through living carbon, by using bioenergy and natural sinks.

\section{Reuse}

Reusing captured carbon through carbon utilization and converting $\mathrm{CO}_{2}$ into durable carbon, including building materials and polymers.

\section{Remove}

Storing captured carbon by converting $\mathrm{CO}_{2}$ into 'durable carbon' via enhanced oil recovery, bioenergy with CCS, direct air capture (and removals via natural sinks).

Crosscutting - Green hydrogen contributing to 'reduce' and 'recycle,' blue hydrogen contributing to 'remove'

G20 Energy Ministers (2020); G20 Climate Stewardship Working Group (2020b)

\begin{tabular}{l|l|}
\hline Reduce & Recycle \\
Lowering emissions through & Neutralizing emissions \\
energy efficiency, renewables & through natural processes \\
(including bioenergy, biofuels) & and decomposition, including \\
and nuclear energy. & $\begin{array}{l}\text { biofuels, bioenergy, and } \\
\text { energy carriers, including } \\
\text { methanol, ammonia and urea. }\end{array}$ \\
\hline
\end{tabular}

Reuse
Converting emissions into
industrial feedstock (carbon
capture and utilization [CCU]),
including via emissions to
value (E2V) and carbon
recycling.

Remove

Removing atmospheric emissions through natural and geological CCS and direct air capture.

\section{Crosscutting - Hydrogen, modern bioenergy and biofuels, energy infrastructures}

AI Saud and AI Shalan (2020); Aramco (2020); IEF (2020); Mansouri et al. (2020)

Reduce
Reducing carbon-based
GHGs emitted into the
atmosphere by employing
efficiency, renewables
capacity, and 'other advanced
systems.'

Recycle

Recycling GHGs or carbonbased products into similar or different products with different chemical characteristics, e.g., urea for fertilizers or 'designer fuels.'

\section{Reuse}

Reusing carbon-based

GHGs without changing their chemistry, e.g., in greenhouses, fizzy beverages or enhanced oil recovery.

\section{Remove}

Removal of carbon-based GHGs from the system, partially (if they will be reused or recycled) or fully (carbon banking [including natural sinks, concrete], storage).

G20 Climate Stewardship Working Group (2020a)

\section{Adaptation actions with mitigation co-benefits}

\section{Water}

Reduce and recycle

Integrated water

management, water reusing

technologies, water use efficiency.

\section{Infrastructure \\ Reduce and recycle}

Sustainable construction materials, resilient natural and built infrastructure, integrated infrastructure planning, coastal protection.

\section{Land}

Reduce, recycle, reuse and remove

Ecosystem sinks, livestock and agriculture carbon management, ecosystem conservation.

\section{Waste}

Reduce, recycle, reuse and remove

Waste to energy, waste management, composting, low-energy and low-carbon construction processes. 


\section{CCE performance sub-index: conceptual considerations}

These conceptualizations should naturally provide the architecture for the sub-index that measures country performance on the CCE. Selecting the building blocks of this dimension, however, involves various decisions, including: (1) which taxonomy to choose; (2) whether and how to build in substitutability between the Rs; and (3) whether to weight different Rs based on their potential contribution to a CCE.

Regarding the first question, using the four Rs would be attractive from a communications perspective, given their link to the concept of the circular economy, which is a better-known concept; the CCE remains a less widely known concept. However, the various ways to divide mitigation options under the CCE umbrella partly reflect country-specific preferences and partly political compromises. Broad consensus on the CCE's categories may therefore not be forthcoming, and picking one taxonomy might alienate those with differing preferences and policy priorities. ${ }^{4}$ Arguably a more constructive approach is to focus instead on the core components that each conceptualization shares. This choice is supported by the fact that applying a specific label to a mitigation option does not impact its contribution to circularity: the atmosphere does not care how emissions are reduced.

A useful selection criterion for the performance dimension of the CCE Index could therefore simply be whether or not they avoid 'fugitive carbon' (for example, some carbon utilization techniques, such as fuels and chemicals, only retain $\mathrm{CO}_{2}$ for brief periods [IEA 2020a], which means they would not qualify). In addition, creating value from $\mathrm{CO}_{2}$ could be a further criterion.
Regarding the second question, arguably substitutability should be allowed when measuring CCE performance: a country can achieve high rates of circularity without employing all Rs, and a country should not be penalized for not employing every component of the CCE, such as, for example, nuclear energy or CCS, if it achieves circularity through other means. At the same time, the contribution of each component under this dimension should add up, given their equal impact on the atmosphere. This also aligns with the spirit of the CCE, as expressed by many of its proponents, of valuing and encouraging all mitigation options (e.g., Sieminski [2020]). In practice, reaching a balance between these considerations that is perceived as 'fair' to all countries is bound to be challenging.

The third question on weighting is perhaps the most challenging one. Globally, while there is confidence that some mitigation options have more potential than others, there is great uncertainty regarding how much each option will eventually contribute to mitigation over the long term. For example, as pointed out in a series of CCE guides developed by KAPSARC $(2020,19)$, significant barriers remain to scaling up carbon utilization. Also, converting $\mathrm{CO}_{2}$ into durable carbon, such as building materials, may not scale up like other mitigation options, as it generally competes with carbon storage which also relies on (costly) carbon capture (KAPSARC 2020, 19). A further example is hydrogen, where significant mitigation potential may exist, but technology development and uptake are still at early stages, making predictions both difficult and premature.

Another aspect of the weighting challenge relates to the national level. References to CCE in the literature refer to it as an approach that can be applied to reflect countries' different circumstances (such as energy endowments) and priorities (for 
example, phasing down fossil fuel production) (e.g., G20 Energy Ministers [2020]; Al Saud and AI Shalan [2020]). The diversity of conditions and preferences means that assigning weights to indicators under this dimension would inevitably introduce an element of bias or subjectivity. ${ }^{56}$

Different indices use different weighting approaches, as discussed in Appendix 2: equal weighting of all variables, weighting based on expert opinion, and weighting based on the statistical relationships between the variables. Each approach has its strengths and weaknesses, and possible solutions to increasing the robustness of the index include exploring the results by using the three approaches (for example, to test if all or two provide similar results) and disclosing the rationale for the selection of the approach and any related choices made.

\section{CCE performance sub-index: possible elements}

In the spirit of the CCE's emphasis on all mitigation and carbon circularity options, the elements of the performance sub-index can be designed by examining the existing CCE taxonomies, which capture the main options available to countries. Other options include $\mathrm{CO}_{2}$ metrics and sectoral policies. However, in the case of $\mathrm{CO}_{2}$ metrics, it could be argued that the index would simply add together already available data on emissions without providing much information about the policy and performance mix of each country. Limited availability of harmonized data, in turn, might complicate the measuring of detailed sector-level developments across countries.

Table 3 presents an initial list of the components of the performance sub-index, as well as suggested indicators and a brief rationale for their selection. Relevance, simplicity and data availability have already been considered in the selection.

\section{CCE enablers sub-index: conceptual considerations}

Indices that measure forward-looking aspects generally focus on examining potential, readiness or enabling environments. However, the former two are challenging in the context of the CCE: data availability is an issue for measuring CCE potential in a technical or physical sense. While harmonized data may be available for technical potential - for example, the International Energy Agency (IEA) (2015) estimated technical EOR storage potential for a number of countries - it is generally not available for economic potential. ${ }^{7}$

Several composite indicators seek to measure readiness. This could be an important dimension to measure, given the significant progress still needed in most countries to achieve carbon neutrality. A review of the components of three CCE-relevant readiness indices (included in Table 1), however, reveals the lack of a shared understanding of what constitutes 'readiness': the CCS Readiness Index, for example, evaluates CCS regulatory frameworks and policy support, but also storage potential and levels of fossil fuel production. The Transition Readiness Score of the Energy Transition Index comprises indicators of investment in sustainable energy, regulatory frameworks, good governance, the business environment and per capita energy use, among others. The Change Readiness Index, in turn, purportedly measures countries' capabilities to manage change via a broad variety of sub-themes, ranging from food security to demographics (but lacks transparency regarding the actual indicators used). ${ }^{8}$

Most of the components covered by these readiness indices can also be understood as components 
Table 3. Possible elements for the 'performance' sub-index of the CCE Index.

\begin{tabular}{|c|c|c|c|}
\hline Dimension & Component & Indicator & Rationale \\
\hline \multirow[t]{11}{*}{$\begin{array}{l}\text { Mitigation } \\
\text { options }\end{array}$} & Energy efficiency & $\begin{array}{l}\text { Energy intensity of the } \\
\text { economy (total energy supply } \\
\text { by GDP) }\end{array}$ & $\begin{array}{l}\text { Energy intensity is the most commonly used measure of energy } \\
\text { efficiency, which in turn contributes to the 'reduce' pillar of the } \\
\text { circular carbon economy. }\end{array}$ \\
\hline & $\begin{array}{l}\text { Renewable } \\
\text { energy }\end{array}$ & $\begin{array}{l}\text { Share of renewable energy of } \\
\text { total energy supply (inter alia, } \\
\text { solar, wind, biofuels, waste and } \\
\text { hydro) }\end{array}$ & $\begin{array}{l}\text { Renewable energy contributes to the 'reduce' and 'recycle' pillars } \\
\text { of the circular carbon economy. }\end{array}$ \\
\hline & Nuclear energy & $\begin{array}{l}\text { Share of nuclear energy of } \\
\text { total energy supply (possibly } \\
\text { merged with renewable energy) }\end{array}$ & $\begin{array}{l}\text { Nuclear energy contributes to the 'reduce' pillar of the circular } \\
\text { carbon economy. }\end{array}$ \\
\hline & $\begin{array}{l}\text { Fuel switching } \\
\text { to lower-carbon } \\
\text { sources }\end{array}$ & $\begin{array}{l}\text { Change in the share of oil and } \\
\text { coal in electricity supply or total } \\
\text { energy mix in last five years }\end{array}$ & $\begin{array}{l}\text { Switching from higher to lower-carbon energy sources supports } \\
\text { the 'reduce' pillar of the circular carbon economy as a transitional } \\
\text { measure (KAPSARC 2020,12). }\end{array}$ \\
\hline & $\begin{array}{l}\text { Green or blue } \\
\text { hydrogen }\end{array}$ & $\begin{array}{l}\text { Green and blue hydrogen } \\
\text { projects (total capacity) }\end{array}$ & $\begin{array}{l}\text { Green hydrogen, produced from renewable energy, contributes to } \\
\text { the 'reduce' and 'recycle' pillars of the circular carbon economy, } \\
\text { and blue hydrogen, produced from hydrocarbons with carbon } \\
\text { capture and storage, contributes to the 'remove' pillar. }\end{array}$ \\
\hline & $\begin{array}{l}\text { Carbon capture } \\
\text { and storage } \\
\text { (including } \\
\text { enhanced oil } \\
\text { recovery) }\end{array}$ & $\begin{array}{l}\text { Total capture capacity } \\
\text { commercial CCS facilities in } \\
\text { operation }\end{array}$ & $\begin{array}{l}\text { CCS contributes to the 'remove' pillar of the circular carbon } \\
\text { economy. Enhanced oil recovery with } \mathrm{CO}_{2} \text { is included as they } \\
\text { appear in the Global CCS Institute's (GCCSI's) outlook report. } \\
\text { According to the International Energy Agency (IEA), } 99 \% \text { of the } \\
\mathrm{CO}_{2} \text { injected via enhanced oil recovery (EOR) ends up being } \\
\text { permanently stored over the lifetime of a project (IEA 2020a, 17). }\end{array}$ \\
\hline & Natural sinks & $\begin{array}{l}\text { Change in forest land/net forest } \\
\text { conversion (or other indicator of } \\
\text { changes in natural sinks) }\end{array}$ & $\begin{array}{l}\text { Net carbon stored in natural sinks contributes to the 'remove' } \\
\text { pillar of the circular carbon economy. Nature-based solutions, } \\
\text { however, run the risk of releasing carbon into the atmosphere } \\
\text { through fires, for example, which is why they are considered } \\
\text { "important complementary options" (KAPSARC, 2020, 15, 17). }\end{array}$ \\
\hline & $\begin{array}{l}\text { Emerging storage } \\
\text { technologies }\end{array}$ & $\begin{array}{l}\text { [Deployment levels still too low/ } \\
\text { data not available to measure] }\end{array}$ & $\begin{array}{l}\text { In } 2019 \text {, there were five facilities worldwide using bioenergy with } \\
\text { carbon capture and storage (BECCS), with a total capacity of } \\
1.5 \text { megatonnes of } \mathrm{CO}_{2} \text { per year (MtCO } \\
4 \text {.) In } 2020 \text {, a total of } 15 \text { direct air capture (DAC) plants were } \\
\text { operational worldwide, with a total capacity of } 9 \text { thousand } \\
\text { tonnes of } \mathrm{CO}_{2} \text { per year (ktCO } \mathrm{K}_{2} \text { /year), and one capture plant with } \\
1 \mathrm{MtCO}_{2} / \text { year was at an advanced stage of development (IEA } \\
2020 \mathrm{~b} \text { ). }\end{array}$ \\
\hline & $\begin{array}{l}\text { Carbon utilization } \\
\text { technologies with } \\
\text { long-term } \mathrm{CO}_{2} \\
\text { retention }\end{array}$ & $\begin{array}{l}\text { [Deployment levels still too low/ } \\
\text { data not available to measure. } \\
\text { An alternative could be overall } \\
\mathrm{CO}_{2} \text { utilization rates.] }\end{array}$ & $\begin{array}{l}\text { Building materials can provide permanent storage for } \mathrm{CO}_{2} \\
\text { Carbon is retained only temporarily in fuels and chemicals (IEA } \\
2020 \mathrm{a}, 11,36 \text { ). }\end{array}$ \\
\hline & $\begin{array}{l}\text { Carbon-neutral } \\
\text { utilization } \\
\text { technologies }\end{array}$ & $\begin{array}{l}\text { [Deployment levels still too low/ } \\
\text { data not available to measure] }\end{array}$ & $\begin{array}{l}\text { Carbon-neutral carbon utilization has not yet been scaled up } \\
\text { globally. According to the IEA, "in the transition to an economy } \\
\text { with net-zero } \mathrm{CO}_{2} \text { emissions, the } \mathrm{CO}_{2} \text { used in fuels and } \\
\text { chemicals production would increasingly need to be sourced from } \\
\text { sustainable biomass or the air (through direct air capture). RD\&D } \\
\text { support for these applications will be important to reduce costs } \\
\text { and accelerate their commercial availability." (IEA 2020a, 6). }\end{array}$ \\
\hline & Electrification & $\begin{array}{l}\text { Share of electricity in total final } \\
\text { energy consumption }\end{array}$ & $\begin{array}{l}\text { Electrifying transport and heating (e.g., via electric vehicles and } \\
\text { heat pumps) with renewable energy is considered crucial for } \\
\text { reducing emissions. According to the International Renewable } \\
\text { Energy Agency (IRENA), it could deliver } 36 \% \text { of the energy-related } \\
\mathrm{CO}_{2} \text { emissions reductions needed between } 2015-2050 \text { to meet the } \\
\text { goals of the Paris Agreement (IRENA 2019). }\end{array}$ \\
\hline
\end{tabular}


of enabling environments. This term also conveys more clearly what it seeks to measure, namely how well the country is positioned to support and enable progress toward CCE. As such, this dimension can also be used as a measure of readiness and even potential in a more generic sense of the word.

\section{CCE enablers sub-index: possible elements}

Possible elements of an 'enablers' sub-index of the CCE Index are listed in Table 4. The elements are based on a survey of CCE-relevant indicators and literature (including those listed in tables 1 and 2) and include suggested indicators and a selection rationale. Similarly to the performance sub-index, relevance, simplicity and availability have been considered in the selection.
Notably, there are a variety of ways of grouping the indicators under different themes, and the proposal in Table 4 is merely intended as a starting point for discussions on sub-dimensions and components, including total numbers and weighting. In terms of weighting and aggregation, equal weighting among sub-dimensions could be the most pragmatic approach, complemented by expert consultation. The sub-dimensions would ideally be designed to distinguish separate but equally important thematic clusters. High performance in one enabler, such as investment, would not be allowed to directly compensate for low performance in another, such as policies. There is general agreement that major system transitions, such as energy transitions, involve broad socioeconomic and political shifts across technological and market structures, and regulatory frameworks, among others (Singh et al. 2019). 
Table 4. Possible elements for the 'enablers' sub-index of the CCE Index.

\begin{tabular}{|c|c|c|c|}
\hline Dimension & Component & Indicator & Rationale \\
\hline \multirow[t]{7}{*}{$\begin{array}{l}\text { Policies, } \\
\text { regulation } \\
\text { and } \\
\text { governance }\end{array}$} & $\begin{array}{l}\text { Policy and } \\
\text { regulatory } \\
\text { support to energy } \\
\text { efficiency }\end{array}$ & $\begin{array}{l}\text { Regulatory Indicators for } \\
\text { Sustainable Energy (RISE) } \\
\text { indicators for energy efficiency }\end{array}$ & $\begin{array}{l}\text { The RISE energy efficiency indicators provide a record of } \\
\text { laws, regulations, and policies enacted by countries. They are } \\
\text { designed as a precursor of progress in energy efficiency and } \\
\text { related investments (World Bank/ESMAP 2020, 9). }\end{array}$ \\
\hline & $\begin{array}{l}\text { Policy and } \\
\text { regulatory } \\
\text { support to } \\
\text { renewable energy }\end{array}$ & $\begin{array}{l}\text { Regulatory Indicators for } \\
\text { Sustainable Energy (RISE) } \\
\text { indicators for renewable energy }\end{array}$ & $\begin{array}{l}\text { The RISE renewable energy indicators provide a record of } \\
\text { laws, regulations, and policies enacted by countries. They are } \\
\text { designed as a precursor of progress in renewable energy and } \\
\text { related investments (World Bank/ESMAP 2020,9). }\end{array}$ \\
\hline & $\begin{array}{l}\text { Carbon capture } \\
\text { and storage law } \\
\text { and regulation }\end{array}$ & $\begin{array}{l}\text { CCS Legal and Regulatory } \\
\text { Indicator and CCS Policy } \\
\text { Indicator, part of CCS } \\
\text { Readiness Index }\end{array}$ & $\begin{array}{l}\text { The 'Legal and Regulatory' indicator focuses on legal and } \\
\text { regulatory frameworks considered critical for the domestic } \\
\text { regulation of CCS operations. The 'Policy' indicator assesses } \\
\text { CCS-specific policy measures, including broader implicit support } \\
\text { through measures including emission reduction targets, carbon } \\
\text { pricing and project funding (Havercroft and Consoli, 2018). }\end{array}$ \\
\hline & $\begin{array}{l}\text { Natural sinks } \\
\text { protection } \\
\text { policies }\end{array}$ & $\begin{array}{l}\text { Average proportion of } \\
\text { terrestrial, freshwater and } \\
\text { marine key biodiversity areas } \\
\text { covered by protected areas }\end{array}$ & $\begin{array}{l}\text { Protected areas play a significant role in sequestering carbon. } \\
\text { Based on some estimates, they sequester one-fifth of the carbon } \\
\text { sequestered by all land ecosystems annually (Melillo et al. 2015). }\end{array}$ \\
\hline & $\begin{array}{l}\text { Measurement, } \\
\text { reporting and } \\
\text { verification (MRV) } \\
\text { of emissions }\end{array}$ & $\begin{array}{l}\text { Fulfillment of reporting } \\
\text { obligations under the United } \\
\text { Nations Framework Convention } \\
\text { on Climate Change (UNFCCC) }\end{array}$ & $\begin{array}{l}\text { Under the UNFCCC, Annex I (developed) and non-Annex I } \\
\text { (developing) countries are required to submit various reports } \\
\text { and participate in periodic reviews/analyses of these reports. } \\
\text { Reporting requirements and the timetables are currently } \\
\text { different for developed and developing countries. By the end } \\
\text { of } 2020 \text {, developed countries should have submitted seven } \\
\text { national communications and four biennial reports. Developing } \\
\text { countries should have (in most cases) submitted six national } \\
\text { communications and four biennial reports. }\end{array}$ \\
\hline & $\begin{array}{l}\text { (Climate change) } \\
\text { governance }\end{array}$ & $\begin{array}{l}\text { Worldwide Governance } \\
\text { Indicators score }\end{array}$ & $\begin{array}{l}\text { In order "to achieve their environmental commitments and goals, } \\
\text { states need strong legislative, political and judicial systems" } \\
\text { (UNEP 2009). This applies to all areas of policy. The Worldwide } \\
\text { Governance Indicators report aggregate and individual } \\
\text { governance indicators for six dimensions of governance. }\end{array}$ \\
\hline & $\begin{array}{l}\text { Climate change } \\
\text { policy ambition }\end{array}$ & $\begin{array}{l}\text { Climate Policy score of the } \\
\text { Climate Change Performance } \\
\text { Index (CCPI) }\end{array}$ & $\begin{array}{l}\text { High policy ambition is necessary for guiding investments and } \\
\text { markets and providing direction for implementation. Evaluating } \\
\text { the ambition of countries' climate change policies inevitably } \\
\text { requires the use of qualitative and subjective measures. } \\
\text { The CCPI is the best-known index of national climate policy } \\
\text { performance. Its Climate Policy section covers the most recent } \\
\text { developments in national climate policy frameworks, based on } \\
\text { a performance rating provided by climate and energy policy } \\
\text { experts for both national and international policy. }\end{array}$ \\
\hline
\end{tabular}




\begin{tabular}{|c|c|c|c|}
\hline \multirow[t]{5}{*}{$\begin{array}{l}\text { Technology, } \\
\text { knowledge } \\
\text { and } \\
\text { innovation }\end{array}$} & $\begin{array}{l}\text { Research and } \\
\text { development } \\
\text { (R\&D) } \\
\text { expenditure }\end{array}$ & $\begin{array}{l}\text { R\&D expenditure (specific to } \\
\text { clean energy technologies, if } \\
\text { possible) }\end{array}$ & $\begin{array}{l}\text { R\&D expenditure is used as a proxy for measuring the public } \\
\text { finance inputs into creating knowledge and fostering innovation } \\
\text { around technology and other solutions that support the circularity } \\
\text { of carbon in the economy. }\end{array}$ \\
\hline & Research output & $\begin{array}{l}\text { Patent applications by } \\
\text { residents/capita (specific to } \\
\text { clean energy technologies, if } \\
\text { possible) }\end{array}$ & $\begin{array}{l}\text { Patent applications are used as a proxy for measuring the } \\
\text { knowledge and innovation outputs around technology and other } \\
\text { solutions that support the circularity of carbon in the economy. }\end{array}$ \\
\hline & Researchers & $\begin{array}{l}\text { Researchers (in full-time } \\
\text { equivalent, specific to clean } \\
\text { energy technologies, if } \\
\text { possible) }\end{array}$ & $\begin{array}{l}\text { Science capacity/innovation potential is often measured by the } \\
\text { number of Ph.D.s or scientists. }\end{array}$ \\
\hline & $\begin{array}{l}\text { High-tech } \\
\text { industry's } \\
\text { contribution }\end{array}$ & $\begin{array}{l}\text { Medium and high-tech } \\
\text { industry value added (of total } \\
\text { manufacturing value added) }\end{array}$ & $\begin{array}{l}\text { "Industrial development generally entails a structural transition } \\
\text { from resource-based and low technology activities to medium } \\
\text { and high-tech industry (MHT) activities. A modern, highly } \\
\text { complex production structure offers better opportunities for skills } \\
\text { development and technological innovation. MHT activities are } \\
\text { also the high value addition industries of manufacturing with } \\
\text { higher technological intensity and labor productivity. Increasing } \\
\text { the share of MHT sectors also reflects the impact of innovation" } \\
\text { (World Bank 2021a). }\end{array}$ \\
\hline & $\begin{array}{l}\text { Technology } \\
\text { connectedness/ } \\
\text { spillover/diffusion }\end{array}$ & Patent citations & $\begin{array}{l}\text { Diffusion of new technologies into/out of a country is just as } \\
\text { important as their invention. }\end{array}$ \\
\hline \multirow[t]{7}{*}{$\begin{array}{l}\text { Sustainable } \\
\text { finance and } \\
\text { investment }\end{array}$} & $\begin{array}{l}\text { Investments in } \\
\text { clean energy }\end{array}$ & $\begin{array}{l}\text { Public Renewable Energy } \\
\text { Finance Flows }\end{array}$ & $\begin{array}{l}\text { Investments in clean energy are crucial for supporting the CCE. } \\
\text { The Public Renewable Energy Finance Flows by IRENA present } \\
\text { an overview of investment transactions for renewable energies } \\
\text { from selected public financial institutions (IRENA 2020). }\end{array}$ \\
\hline & $\begin{array}{l}\text { Sustainable } \\
\text { finance access }\end{array}$ & $\begin{array}{l}\text { Sustainable finance } \\
\text { instruments, such as green, } \\
\text { social and sustainability-linked } \\
\text { debt (bonds and loans) issued } \\
\text { per country of domicile (latest } \\
\text { five years) }\end{array}$ & $\begin{array}{l}\text { Achieving net-zero carbon emission goals requires a multi-trillion } \\
\text { U.S. dollar (US\$) investment into various sustainability projects, } \\
\text { such as renewables, CCU technologies, energy efficiency and } \\
\text { innovation projects, which is far beyond the capacity of public } \\
\text { resources. The involvement of private finance is instrumental in } \\
\text { bridging this gap. Therefore, countries' access to sustainable } \\
\text { finance instruments is essential to finance various sustainability } \\
\text { projects related to energy transitions. }\end{array}$ \\
\hline & $\begin{array}{l}\text { Investments in } \\
\text { energy efficiency }\end{array}$ & $\begin{array}{l}\text { [Datasets not found in first } \\
\text { review of indicators] }\end{array}$ & $\begin{array}{l}\text { Investments in energy efficiency are crucial for supporting the } \\
\text { CCE. }\end{array}$ \\
\hline & $\begin{array}{l}\text { Investments in } \\
\text { carbon capture, } \\
\text { utilization and } \\
\text { storage }\end{array}$ & $\begin{array}{l}\text { [Datasets not found in first } \\
\text { review of indicators] }\end{array}$ & Investments in CCUS are crucial for supporting the CCE. \\
\hline & $\begin{array}{l}\text { Stock market } \\
\text { environmental, } \\
\text { social and } \\
\text { corporate } \\
\text { governance } \\
\text { (ESG) reporting }\end{array}$ & $\begin{array}{l}\text { Share (or number) of firms } \\
\text { providing ESG reporting (if } \\
\text { possible, adjusted by their } \\
\text { market value) }\end{array}$ & $\begin{array}{l}\text { Besides governments, firms should also transition toward CCE } \\
\text { goals. More transparent reporting of environmental aspects of } \\
\text { business activities can help them become more attractive to } \\
\text { sustainability investors. }\end{array}$ \\
\hline & $\begin{array}{l}\text { Green loan } \\
\text { access (firms and } \\
\text { households) }\end{array}$ & $\begin{array}{l}\text { [Datasets not found in first } \\
\text { review of indicators] }\end{array}$ & $\begin{array}{l}\text { Green loans are particularly important to enable small and } \\
\text { medium-sized enterprises (SMEs) or households to invest in } \\
\text { energy efficiency and small renewable projects. }\end{array}$ \\
\hline & $\begin{array}{l}\text { Carbon pricing/ } \\
\text { valuation policies/ } \\
\text { markets }\end{array}$ & $\begin{array}{l}\text { Emissions trading scheme } \\
\text { or carbon tax implemented, } \\
\text { scheduled or under } \\
\text { consideration }\end{array}$ & $\begin{array}{l}\text { Pricing or valuing carbon is essential for enabling the CCE. The } \\
\text { World Bank's carbon pricing dashboard provides qualitative } \\
\text { information on plans for and the implementation of emissions } \\
\text { trading schemes and carbon taxes in national and sub-national } \\
\text { jurisdictions. }\end{array}$ \\
\hline
\end{tabular}




\begin{tabular}{|c|c|c|c|}
\hline \multirow[t]{4}{*}{$\begin{array}{l}\text { Business and } \\
\text { investment } \\
\text { environment } \\
\text { and } \\
\text { infrastructure }\end{array}$} & $\begin{array}{l}\text { Regulations } \\
\text { supporting } \\
\text { business activity }\end{array}$ & $\begin{array}{l}\text { Ease of Doing Business } \\
\text { score }\end{array}$ & $\begin{array}{l}\text { The Ease of Doing Business score is used as a proxy for } \\
\text { regulatory environments that support entrepreneurship and } \\
\text { business activity. Businesses are important, among other things, } \\
\text { for supporting the monetization of } \mathrm{CO}_{2} \text { and supporting the } \\
\text { scale-up of various CCE-related technologies. }\end{array}$ \\
\hline & $\begin{array}{l}\text { Renewable } \\
\text { energy } \\
\text { investment and } \\
\text { deployment } \\
\text { opportunities }\end{array}$ & $\begin{array}{l}\text { Renewable Energy Country } \\
\text { Attractiveness Index } \\
\text { (RECAI) }\end{array}$ & $\begin{array}{l}\text { The RECAI seeks to measure what in Ernst \& Young's (EY's) } \\
\text { assessment are the factors that drive market attractiveness of } \\
\text { renewable energy (a key component of a CCE for all countries), } \\
\text { including growing energy demand (or the need to replace energy } \\
\text { technologies), support/obstacles from policy, support for project } \\
\text { delivery, including long-term contracts, grid infrastructure and } \\
\text { finance, track record in projects and the overall investment } \\
\text { climate (EY 2021). }\end{array}$ \\
\hline & $\begin{array}{l}\text { Trade and } \\
\text { transport } \\
\text { infrastructure }\end{array}$ & $\begin{array}{l}\text { Logistics Performance } \\
\text { Index }\end{array}$ & $\begin{array}{l}\text { Strong and functioning trade and logistics chains can lower trade } \\
\text { costs and support country competitiveness (World Bank 2021b). } \\
\text { Given countries' different natural endowments and competitive } \\
\text { advantages, trade can help lower the costs of managing } \mathrm{CO}_{2} \text {. }\end{array}$ \\
\hline & $\begin{array}{l}\text { Energy } \\
\text { infrastructure and } \\
\text { security }\end{array}$ & $\begin{array}{l}\text { Energy Security dimension } \\
\text { of the Energy Trilemma } \\
\text { Index }\end{array}$ & Energy security supports the CCE in fundamental ways. \\
\hline \multirow[t]{7}{*}{$\begin{array}{l}\text { Socioeconomic } \\
\text { indicators }\end{array}$} & $\begin{array}{l}\text { (Economy) } \\
\text { Economic growth }\end{array}$ & $\begin{array}{l}\text { Annual growth rate of real } \\
\text { (or purchasing power parity } \\
\text { [PPP] current international } \\
\text { US\$) GDP per capita, } \\
\text { three-year average }\end{array}$ & $\begin{array}{l}\text { Considering the global tendency toward a more sustainable } \\
\text { economic system, countries need to reorganize and adjust their } \\
\text { local systems in order to sustain their long-term economic growth } \\
\text { trajectories. }\end{array}$ \\
\hline & $\begin{array}{l}\text { (Economy) } \\
\text { Economic } \\
\text { diversification }\end{array}$ & Economic complexity score & $\begin{array}{l}\text { The Economic Complexity Index ranks countries based on how } \\
\text { diversified and complex their export baskets are. Countries } \\
\text { with higher levels of economic complexity are better equipped } \\
\text { for transitioning in a timely manner toward more inclusive, } \\
\text { sustainable, affordable and secure energy systems (WEF 2020, } \\
12,37 . \text { ) }\end{array}$ \\
\hline & $\begin{array}{l}\text { (Finance) } \\
\text { Access to private } \\
\text { finance }\end{array}$ & $\begin{array}{l}\text { Domestic credit-to-GDP } \\
\text { ratio }\end{array}$ & $\begin{array}{l}\text { While sustainable finance instruments are specifically designed } \\
\text { for large-scale sustainability projects, private finance instruments } \\
\text { are key enablers of small-scale sustainability projects (e.g., } \\
\text { renewable energy development, energy efficiency improvements) } \\
\text { for SMEs and households. }\end{array}$ \\
\hline & $\begin{array}{l}\text { (Finance) } \\
\text { International } \\
\text { (financial) } \\
\text { connectedness }\end{array}$ & $\begin{array}{l}\text { Foreign direct investment } \\
\text { inflows }\end{array}$ & Important for global capital investment projects. \\
\hline & $\begin{array}{l}\text { (Finance) } \\
\text { Access to equity } \\
\text { markets }\end{array}$ & $\begin{array}{l}\text { Stock market capitalization/ } \\
\text { GDP }\end{array}$ & A key factor for large firms and related investments. \\
\hline & $\begin{array}{l}\text { (Finance) } \\
\text { Access to money } \\
\text { markets }\end{array}$ & $\begin{array}{l}\text { Private money (bond) } \\
\text { market size/GDP }\end{array}$ & A key factor for large firms and related investments. \\
\hline & $\begin{array}{l}\text { (Social) } \\
\text { Energy access }\end{array}$ & $\begin{array}{l}\text { Energy Equity dimension of } \\
\text { the Energy Trilemma Index }\end{array}$ & $\begin{array}{l}\text { Energy access and affordability support the CCE in fundamental } \\
\text { ways. The Energy Equity dimension of the World Energy } \\
\text { Council's Energy Trilemma Index measures energy access, the } \\
\text { quality of energy access, and energy affordability. }\end{array}$ \\
\hline
\end{tabular}




\begin{tabular}{|l|l|l}
\hline $\begin{array}{l}\text { (Social) } \\
\text { Human capital }\end{array}$ & Human Capital Index & $\begin{array}{l}\text { Human capital supports the CCE in fundamental ways. Scaling } \\
\text { up net-zero infrastructure and energy efficiency requires a large, } \\
\text { skilled workforce. The Human Capital Index "calculates the } \\
\text { contributions of health and education to worker productivity. The } \\
\text { final index score...measures the productivity as a future worker } \\
\text { of child born today relative to the benchmark of full health and } \\
\text { complete education." (World Bank 2020b) }\end{array}$ \\
\hline $\begin{array}{l}\text { (Social) } \\
\text { Employment }\end{array}$ & $\begin{array}{l}\text { Employment to population } \\
\text { ratio, 15+, total (modeled } \\
\text { International Labour } \\
\text { Organization estimate) }\end{array}$ & High employment rates support the CCE in fundamental ways. \\
\hline $\begin{array}{l}\text { (Environmental) } \\
\text { Environmental } \\
\text { health }\end{array}$ & $\begin{array}{l}\text { Mortality rate attributed to } \\
\text { household and ambient air } \\
\text { pollution, age-standardized }\end{array}$ & $\begin{array}{l}\text { Air pollution is one of the biggest environmental risks to health, } \\
\text { causing an estimated 7 million premature deaths annually (WHO } \\
\text { 2021). Given that fossil fuels are a major source of air pollution, } \\
\text { lower levels of air pollution generally indicate their better } \\
\text { management and also carbon circularity. }\end{array}$ \\
\hline $\begin{array}{l}\text { (Environmental) } \\
\text { Climate change } \\
\text { adaptation/ } \\
\text { resilience }\end{array}$ & $\begin{array}{l}\text { Global Climate Risk Index } \\
\text { (GCRI) }\end{array}$ & $\begin{array}{l}\text { A country's resilience to climate risks supports the CCE in } \\
\text { fundamental ways. The GCRI quantifies the impacts of extreme } \\
\text { weather events (fatalities and economic losses). }\end{array}$ \\
\hline
\end{tabular}




\section{Oil producers' lens: possible elements}

An additional set of indicators, or lens, for oil producers and their national oil companies (NOCs) could be considered given their CCE-related structural similarities, as well as CCE-related challenges and opportunities that set them apart from other countries. Table 5 presents suggestions for performance metrics and enablers for this sub-index. Due to the initial stages of development of this lens, the links to the respective components are not elaborated for oil company-level indicators.

Table 5. Possible elements for an oil producers' lens.

\begin{tabular}{|c|c|c|c|}
\hline Dimension & Component & Indicator & Rationale \\
\hline \multirow[t]{4}{*}{ Performance } & $\begin{array}{l}\text { (Country level) } \\
\text { Carbon intensity of the } \\
\text { energy mix }\end{array}$ & $\begin{array}{l}\mathrm{CO}_{2} \text { intensity of the energy mix (possibly } \\
\text { included in the main performance index) }\end{array}$ & $\begin{array}{l}\text { Lower carbon intensity. The energy mix } \\
\text { contributes to the 'reduce' pillar of the CCE. }\end{array}$ \\
\hline & $\begin{array}{l}\text { (Country level) } \\
\text { GHG intensity of fossil fuel } \\
\text { production }\end{array}$ & $\begin{array}{l}\text { Volume-weighted average carbon } \\
\text { intensity of crude oil production, } \\
\text { transportation and refining by source } \\
\text { country }\end{array}$ & $\begin{array}{l}\text { A lower carbon intensity of crude oil } \\
\text { production contributes to the 'reduce' pillar } \\
\text { of the CCE. }\end{array}$ \\
\hline & $\begin{array}{l}\text { (Country level) } \\
\text { Flaring and venting } \\
\text { intensity }\end{array}$ & $\begin{array}{l}\text { Intensity of fugitive emissions from } \\
\text { methane from the hydrocarbon industry }\end{array}$ & $\begin{array}{l}\text { The primary goal of the CCE is to minimize } \\
\text { atmospheric GHG emissions. Capturing } \\
\text { value from hydrocarbons is another } \\
\text { important goal. The fewer fugitive emissions } \\
\text { an industry produces, the better it is at } \\
\text { delivering on these two goals. }\end{array}$ \\
\hline & $\begin{array}{l}\text { CCS-to-fossil-fuel- } \\
\text { production ratio }\end{array}$ & $\begin{array}{l}\text { [Deployment levels still too low/data not } \\
\text { available to measure] }\end{array}$ & \\
\hline \multirow[t]{10}{*}{ Enablers } & $\begin{array}{l}\text { (Country level) } \\
\text { Quality of resource } \\
\text { governance }\end{array}$ & $\begin{array}{l}\text { Value Realization Score of the Resource } \\
\text { Governance Index }\end{array}$ & $\begin{array}{l}\text { The quality of governance around } \\
\text { exploration, production, environmental } \\
\text { protection, revenue collection and } \\
\text { state-owned enterprises are aspects of } \\
\text { resource governance that contribute to } \\
\text { realizing public value from a country's oil, } \\
\text { gas and minerals, and protect a country's } \\
\text { local environment and communities (NRGI } \\
2017,4) \text {. }\end{array}$ \\
\hline & $\begin{array}{l}\text { ESG or sustainability } \\
\text { reporting }\end{array}$ & Annual EGS reporting & \\
\hline & Climate risk disclosure & Existence of climate risk assessment & \\
\hline & $\begin{array}{l}\text { Accounting for scope } 1 \\
\text { emissions }\end{array}$ & Availability of scope 1 emissions data & \\
\hline & $\begin{array}{l}\text { Accounting for scope } 2 \\
\text { emissions }\end{array}$ & Availability of scope 2 emissions data & \\
\hline & $\begin{array}{l}\text { Accounting for scope } 3 \\
\text { emissions }\end{array}$ & Availability of scope 3 emissions data & \\
\hline & Carbon intensity target & Existence of a target & \\
\hline & Methane intensity target & Existence of a target & \\
\hline & Carbon neutrality target & Existence of a target & \\
\hline & $\begin{array}{l}\text { Investments in CCE } \\
\text { technologies }\end{array}$ & [Unclear if quantifiable at company level] & \\
\hline
\end{tabular}


In summary, Figure 1 presents a visualization of the proposed conceptual framework of the CCE Index, with the performance sub-index shown at the component level with linkages to the four Rs of the CCE. The enablers sub-index is illustrated only at the dimension level.

In terms of the CCE Index approach as a whole, underlying assumptions include:

- The indicators may evolve in future editions of the index as new data becomes available, as the concept of the CCE or related technologies evolve, and to ensure the availability of data for all countries measured (should the Index be applied to a larger group of countries).
- The index is developed through domestic and international stakeholder and expert consultation to ensure robustness and to increase the ownership of the index.

- The index methodology, including choices made relating to weighting and aggregation and related justifications, should be made publicly available.

Figure 1. Visualization of the CCE Index conceptual framework.

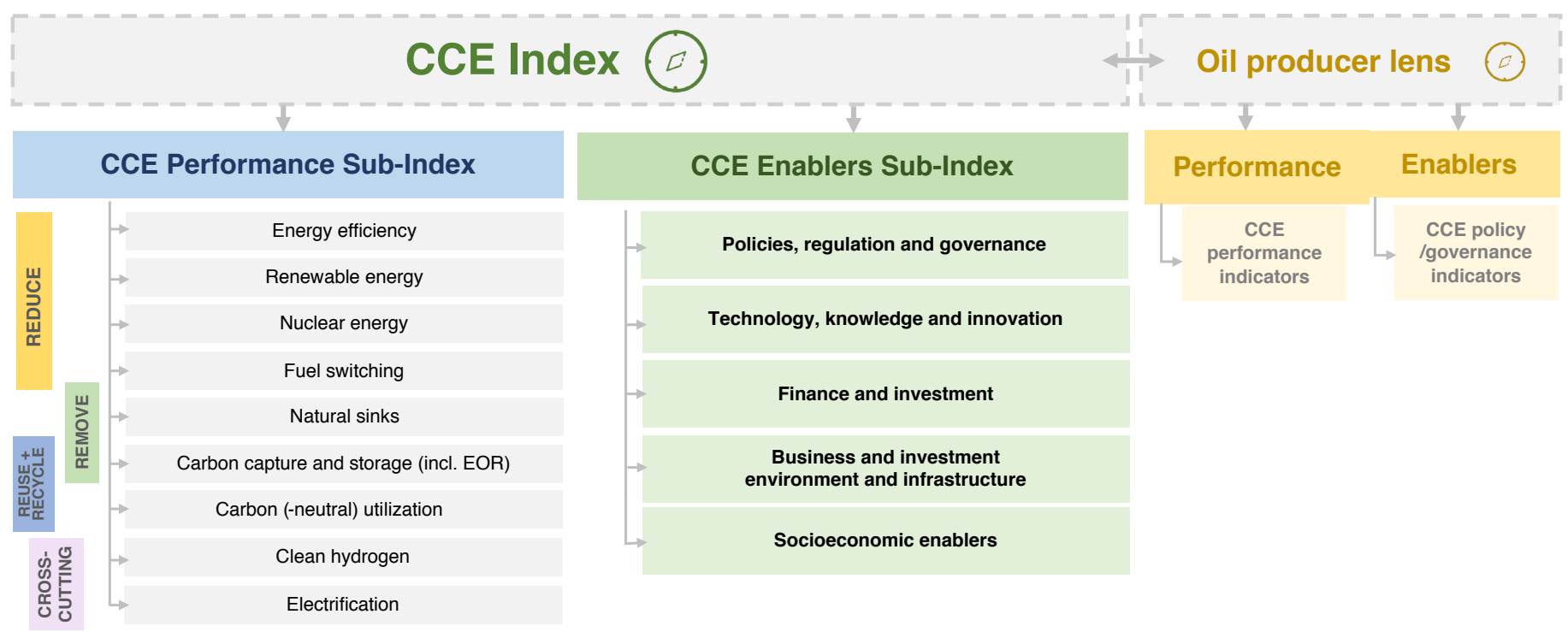




\section{Best Practice in Index Development and Next Steps}

$B$ est practice in the development of composite indicators is relatively well established.

Manuals have been developed by the European Commission's Joint Research Centre (JRC 2004), the OECD (2008), Eurostat (2014, 2017a, 2017b) and the United Nations Economic Commission for Europe (UNECE 2019), among others. The OECD also published a quality framework and toolbox for composite indicators, containing detailed methodological guidance for index developers on various steps described below (OECD 2008).

The conceptual framework and the selection, weighting and aggregation of indicators are the most crucial steps when developing socioeconomic indices (UNECE 2019). A number of other steps involving data analysis, stakeholder engagement and communication are also important. Below is a description of the main steps involved in developing a socioeconomic composite indicator, along with related key methodological considerations, based on these sources.

Key steps in the development of a composite indicator include:

1. Development of a conceptual framework

2. Data selection and preparation

3. Data processing

4. Data analysis

5. Presentation of the results and effective use

6. Crosscutting: stakeholder engagement
The development of the CCE Index will be based on these steps, which are described in detail in Appendix 2.

As the next steps in the index, the conceptual framework and initial indicators will be developed further during the spring and summer of 2021 by the CCE Index project team in consultation with domestic and international CCE stakeholders. Stakeholder consultations will include workshops, webinar presentations, targeted expert consultations, and possibly a web-based expert survey. The CCE Index methodology will be finalized later in 2021 by the project team and peer-reviewed internally and externally. The Index, including an analysis of the results and the final methodology, will be made available in a report and possibly via an interactive webpage. The Index will be disseminated through relevant national and international events. 


\section{Appendix 1. Characteristics of Socioeconomic Indices}

As shown in Table 1, socioeconomic composite indicators can have different temporal foci: the HDI, for example, measures countries' current performances on human development. The SDG Index, in turn, measures a country's performance relative to achieving an SDG indicator, target or goal, based on either an absolute benchmark (e.g., zero poverty) or an average of top-performing countries. The SDG Dashboards also present trends, which measure whether a country is on track to achieve an SDG based on two or more historical data points. The CCS Readiness Index estimates "opportunities" for the deployment of CCS projects in countries, based on measures of storage capacity, legal and policy readiness and perceived interest.

Indicators also measure different aspects of policy. For example, the Global Innovation Index measures countries' innovation performance, the Energy Trilemma Index weighs how countries balance three sometimes conflicting goals relating to energy policy and performance, and the Regulatory Indicators for Sustainable Energy (RISE) indicators, or the Ease of Doing Business score, assess enabling environments.

Alongside composite indicators, other types of indices include 'leading' and 'sentiment' indicators. Leading indicators aim to predict outcomes, whereas sentiment indicators measure subjective opinions, attitudes or expectations (UNECE 2019, 10). For example, the the Sustainable Development Solutions Network's (SDSN's) World Happiness Index is based entirely on individuals' life satisfaction perceptions. The three categories of indicators - composite, leading and sentiment - are not mutually exclusive, and many composite indicators include subjective measures. Germanwatch's Climate Change Performance Index, for example, draws from 350-400 expert assessments of countries' national and international policy performance. The World Bank's Ease of Doing Business includes measures of time (e.g., starting a local limited liability company) that represent median values reported by surveyed respondents. Many indices also include entire composite indicators as sub-indicators. For example, the World Intellectual Property Organization's (WIPO's) Global Innovation Index's 2020 edition is based on 58 'hard data' indicators, 18 composite indicators and four survey questions.

Generally, composite indicators contain several sub-indices and/or dimensions, representing various domains or aspects of the concept or issue being measured (see Table 1). A large degree of subjectivity is involved in designing both the dimensions and their individual indicators, and choices regarding which indicators to include and how to weight and aggregate them are therefore important (UNECE 2019). Conceptual frameworks that explain how the index and its indicators relate to the concept or phenomenon it seeks to measure, combined with a robust and transparent methodological approach, are considered key features of a high-quality index. 


\section{Appendix 2. Methodological Approach to Developing the CCE Index}

\section{1) Development of a conceptual framework. Establishing a conceptual framework is the first step in} developing a socioeconomic index. The framework should define the concept or phenomenon that is being measured, along with related concepts. As an overarching principle, there should be an interpretable relationship between the index and the concept being measured. The framework should also contain an explanation of what the index aims to measure and what its intended uses are (see e.g., Eurostat [2017b], 17). The sub-indices and dimensions of the index should also be specified and reflected in a way that allows for selecting, combining and weighing the indicators. The number of dimensions should be manageable, but each dimension can contain several indicator variables. The conceptual framework should also indicate the relationships between the dimensions and indicators, and it may already specify the logic for indicator weighting and aggregation. A description of indicator selection criteria can be helpful (JRC 2004; UNECE 2019; OECD 2008; Lafortune et al. 2018).

It may be also useful to decide during this phase which countries the index will seek to measure, as data availability often has significant implications for indicator selection. Some indices, such as the SDG Index, specify a percentage threshold for indicator inclusion based on data availability for the countries being measured.

2) Data selection and preparation. Selecting the indicators should happen through a careful review of available data/indicators. Key selection principles include relevance, simplicity, validity and data availability (JRC 2004). Other important considerations are:

- The selection of the indicators should be explained and linked to theory or research when possible (UNECE 2019).

- The availability of indicator data for future updates should be considered if the intention is to measure trends.

- Harmonized data should be used for indices that make cross-country comparisons (UNECE 2019).

The complexity of the concept being measured generally determines the number of necessary indicators. The developers should also consider whether and how to use input (e.g., R\&D investments) and output/ outcome/impact (e.g., number of patents) indicators, and sentiment and objective indicators. Some guidance advises against using input indicators when measuring country performance (OECD 2008).

After selecting the most promising indicators, the index developers should prepare the data for further analysis. This phase generally involves data retrieval to examine various potential indicators' data quality, the availability of data for the intended group of countries, and the data availability over time, which can be time-intensive.

(Continued on next page) 
Appendix 2. (continued)

Undertaking stakeholder consultations in this phase (and in relation to the conceptual framework) are considered good practice (UNECE 2019). Consultations should target both index users and topic experts. If the index developers engage in a thorough data review and extensive stakeholder consultations, this phase can be time-intensive.

The subsequent steps involve analysing the data series and the relation between these through various statistical methods, which can be divided into two main categories: data processing, and data analysis (UNECE 2019).

3) Data processing. Data processing involves various steps:

Imputation: Although data availability for all countries the index expects to measure should be among the key indicator selection criteria, avoiding missing indicator data or datapoints is practically impossible. Index developers should therefore carefully assess the methods available for estimating missing values (OECD 2008).

Normalisation: Methods to make data comparable include: adopting a scale (e.g., 0-100); using the distance from the best and worst performers, the mean or the group leader; or calculating the standard deviation from the mean value (JRC 2004). The direction of the relationship between indicators and the targeted concept should also be normalized (i.e., increasing scores should always imply an improvement on the indicator). Possible outliers (i.e., data points that can distort the results) should also be identified and treated, usually via trimming or winsorization (i.e., excluding extreme values) (UNECE 2019).

Weighting and aggregation: Weighting and aggregation involve important choices as they can significantly impact the final index scores. Weighting should be "in line with the conceptual framework and the intended use of the indicator" (UNECE 2019, 79). The most common weighting method for composite indicators is to assign all indicators an equal weight. For example, the Energy Transition Index uses this approach. The main idea behind this approach is that the relationship between the variables cannot be captured perfectly and, therefore, no structure should be imposed on this relationship. However, even this might result in implicit weighting if, for example, one dimension has a higher number of indicators compared with others (Lafortune et al. 2018). Some indices opt for weighting based on expert opinion - either the index developers' or external - which involves an element of subjectivity. For instance, putting more emphasis on environmental variables in an index focused on climate change recognizes their importance for this issue. The Energy Trilemma Index is one example of an index using expert-informed weighting.

(Continued on next page) 


\section{Appendix 2. (continued)}

There are also statistical methods, including principal component and factor analysis, that provide weights based on commonalities and differences among the variables (e.g., through a variance-covariance matrix) (UNECE 2019, 57; Jolliffe 2002). The Renewable Energy Transition Potential Index, developed by Yilmaz (2021), uses different statistical methods, including principal component analysis for weighting. Greco et al. (2019) provide a rich discussion of the strengths and weaknesses of each of these approaches.

The above-described statistical analysis methods can also be used for examining the structure of the dataset and relations between the potential indicators, including with regard to their overall balance, as well as their suitability and sufficiency vis-à-vis their respective dimensions, the conceptual framework and the concept being measured (OECD 2008).

Compared with purely economic composite indicators (which often operate in monetary units), socioeconomic composite indicators have been criticized for combining measures that lack a common unit of measurement (UNECE 2019). To avoid taking a stance on attributing weights to the components or losing information in the aggregation process, some indices do not provide a total score, but rather present indicators individually in dashboards or scoreboards. The OECD's Better Life Index, for example, allows users themselves to manipulate the weights through a web-based dashboard (http://www. oecdbetterlifeindex.org/). User-defined weights can be useful when there is a significant subjective element involved in defining the concept being measured (e.g., quality of life), and arguably also when a concept lacks a single, agreed definition and/or when different stakeholders place different amounts of emphasis on specific aspects of the concept (such as in the case of CCE).

Aggregation typically involves two steps: from individual indicators to dimensions, and from dimensions to the index (UNECE 2019).

4) Data analysis. After calculating the results, the index should be evaluated for robustness and validity using various methods:

Robustness tests: The robustness and quality of the index should be assessed, including in relation to responses to changes in individual indicators and weights (UNECE 2019). Experts have suggested the use of uncertainty and sensitivity analyses to ensure the index is meaningful, sends a clear and robust policy message and is transparent and well communicated (Saisana et al. 2005). Related questions include how country ranks compare with the most likely ranks under all possible scenarios, which countries are the most volatile, and what are the largest influences on the scores (European Commission 2020). 


\section{Appendix 2. (continued)}

Performance and validity tests: The index developers should assess whether the correlations between the individual indicators and the index are as expected (UNECE 2019). Deconstructing the index into its dimensions or even indicators can support the analysis of its results. Related methods can include visual presentations of the relative contributions of each dimension to individual countries' scores to identify areas of strengths and weaknesses (OECD 2008).

The results of the index should also be compared with other relevant statistics and indices, including to identify possible correlations (e.g., by using cross-plots). The relationship between the index and the potential proxies of what it seeks to measure (such as, in the case of the CCE Index, a country's total annual $\mathrm{CO}_{2}$ emissions) can be tested via correlation and regression analysis. This can help with developing narratives for communicating the results of the index (UNECE 2019; OECD 2008).

5) Presentation of the results and effective use: Presentation of the index results and scores involves drafting a description of the full methodology adopted, including the conceptual framework, and providing an analysis and interpretation of the results. The choice of indicators and weights should in particular be justified, documented and explained (UNECE 2019). The documentation and related explanations should ensure the correct understanding and use of the index to help avoid misunderstandings, and the underlying data should be made available to users as far as possible (UNECE 2019).

Socioeconomic indices render themselves to various types of outputs that can be targeted at different audiences, such as decision-makers, other data users and researchers. In addition to simple index rankings, maps and scoreboards, well-tested, effective ways to communicate index results include:

- Periodical index reports which can include a thematic focus on topical global or country-specific issues.

- Web-based dashboards, which include a visual representation of the index data and can also incorporate interactive tools, such as allowing users to toggle indicator weights or create policy simulations under reasonable scenarios (interactivity with target audiences is considered crucial).

- Making the underlying data available and inviting feedback from peers and data users on the index, which can be valuable for developing further iterations of the index.

6) Crosscutting - stakeholder engagement: Stakeholder consultations are an important crosscutting element in developing indices: they can help improve the quality and policy relevance of the index, and increase its ownership, use and impact. UNECE (2019) has suggested three specific stages: at the outset of the process, to inform the design; during the design and development stages (e.g., during indicator selection and normalisation/weighting); and finally during the dissemination phase. 


\section{Endnotes}

${ }^{1}$ Circular economy focuses on flows of resources, materials and products. It is a model achieving sustainable consumption and production (SCP) through circularity, or ensuring that value is retained as long as possible and, eventually, at the end of their lifecycles, resources, materials and products are returned to the product cycle. The CCE, in turn, focuses on energy and emissions. It builds on three core elements of the circular economy (reduce, reuse and recycle) and adds a fourth one (remove).

${ }^{2}$ The Ellen MacArthur Foundation has developed various company-level tools, including the Material Circularity Indicator and the Circulytics tool.

${ }^{3}$ Saudi-affiliated scholars have drawn attention to how assigning a value to $\mathrm{CO}_{2}$ can help manage it (e.g., Mansouri et al. [2020]). Pricing or valuing $\mathrm{CO}_{2}$ will be essential for realizing the potential of fossil fuel-based mitigation strategies (GCCSI 2020). A CCE approach can also help to identify related domestic and international 'choke points' (KAPSARC, 2020). One such example is CCS, which many countries are likely to need on a large scale in order to reach net-zero emissions by mid-century. Mitigation technologies and options for hard-to-abate sectors, such as energy-intensive industries or aviation and shipping, are other areas where a CCE lens can help to focus efforts.

${ }^{4}$ Also, the Rs are not a functional taxonomy for measuring enablers (the other CCE Index sub-index), as many components/indicators that are likely to be included will have direct relations with multiple Rs. For instance, more ambitious climate change policies or research and development (R\&D) spending can benefit various mitigation technologies.

${ }^{5}$ Equal weighting might therefore be the most pragmatic approach, even if it does not resolve the fact that some technologies by default tend to deliver larger-scale reductions than others (for example, renewable power compared with direct air capture over the medium term).

${ }^{6} \mathrm{~A}$ final consideration is that, given that this sub-index measures performance, it should ideally be composed of output rather than input indicators, following best practice.

${ }^{7}$ The World Bank (2020a), for example, has produced estimates for economic photovoltaic (PV) power potential for a number of countries. However, the study shows that electricity tariffs can have a significant impact on the profitability of this technology.

${ }^{8} \mathrm{~A}$ further example is climate finance readiness which, despite a considerable amount of work being conducted in the area by both international institutions and researchers, lacks an official definition. 


\section{References}

Al Saud, Noura, and Mashael AI Shalan. 2020. "The Circular Carbon Economy: A Global Blueprint for Carbon Circularity \& The Deployment of a Saudi Circular Carbon Economy Program." Discussion Paper, April, 2020. AEON Collective. https://static1.squarespace.com/ static/5d6d0c638a813e000101ddfc/t/5e9f1e7a9480a0 4441a28d7a/1587486336733A+Global+Blueprint+for+ Carbon+Circularity+\&+The+Deployment+of+a+Saudi+ Circular+Carbon+Economy+Program+\%7C+V.2.0..pdf

Alshehri, Thamir, Jan Frederik Braun, Nicholas Howarth, Alessandro Lanza, and Mari Luomi. n.d. "Saudi Arabia's Climate Change Policy and the Circular Carbon Economy Approach." Academic journal manuscript submitted for review in February 2021.

Bandura Romina. 2006. A Survey of Composite Indices Measuring Country Performance: 2006 Update. United Nations Development Programme (UNDP) - Office of Development Studies. https://www.undp.org/content/ dam/undp/library/corporate/Development\%20Studies/ indices_2008_bandura.pdf

Consoli, Christopher P., lan Havercroft, and Lawrence Irlam. 2017. "Carbon capture and storage readiness index: comparative review of global progress towards wide-scale deployment." Energy Procedia 114: 73487355, doi: 10.1016/j.egypro.2017.03.1585

European Commission. 2018. "Measuring progress towards circular economy in the European Union - Key indicators for a monitoring framework." Commission Staff Working Document 17 final, bbJanuary 16. https://eur-lex. europa.eu/legal-content/EN/TXT/?uri=SWD:2018:17:FIN

---. 2020. "Step 8: Sensitivity analysis." Competence Centre on Composite Indicators and Scoreboards. Updated June, 17, 2020, https:// composite-indicators.jrc.ec.europa.eu/?q=10-step-guide/ step-8-sensitivity-analysis

Eurostat. 2014. Towards A Harmonised Methodology for Statistical Indicators. Part 1 - Indicator Typologies and Terminologies. 2014 edition. Luxembourg: Publication Office of the European Union. https://ec.europa.eu/ eurostat/web/products-manuals-and-guidelines/-I ks-gq-14-011

- - -.2017a. Towards A Harmonised Methodology for Statistical Indicators. Part 2 - Communicating through Indicators. 2017 edition. Luxembourg: Publication Office of the European Union. https://ec.europa.eu/eurostat/ web/products-manuals-and-guidelines/-/ks-gq-17-001
- - - 2017b. Towards A Harmonised Methodology for Statistical Indicators. Part 3 - Relevance of Indicators for Policy Making. 2017 edition. Luxembourg: Publication Office of the European Union. https://ec.europa.eu/ eurostat/web/products-manuals-and-guidelines/-/ ks-gq-17-007

Ernst \& Young (EY). 2021. "Renewable Energy Country Attractiveness Index (RECAI)." Accessed January 16, 2021. https://www.ey.com/en_es/recai

European Commission Joint Research Centre (JRC). 2004. "Composite Indicators - A Review." Presentation by Michaela Saisana at the Second Workshop on Composite Indicators of Country Performance, Paris, February 26-27, 2004. https://www.oecd.org/sti/ ind/29398640.pdf

G20 Climate Stewardship Working Group. 2020a. "Adaptation in the Context of the Circular Carbon Economy." Presidency Report. September 2020. https:// www.g20.gov.sa/en/g20/Documents/G20\%20CSWG\%20 Outcome_Adaptation $\% 20$ in $\% 20$ the $\% 20$ Context $\% 20$ of\%20the\%20CCE\%20Platform_Final_.pdf

G20 Climate Stewardship Working Group. 2020b. "Managing Emissions in the Context of the Circular Carbon Economy Platform." Presidency Report. September 2020. https://www.g20.gov.sa/en/g20/ Documents/G20\%20CSWG\%20Outcome_Managing\%20 Emissions\%20in\%20the\%20Context\%20of\%20the\%20 CCE\%20Platform_Final_.pdf

G20 Energy Ministers. 2020. "G20 Energy Ministers Communique." September 27-28. http://www.g20. utoronto.ca/2020/G20SS_Energy_Ministers_Meeting_ Communique.pdf

G20 Saudi Arabia. 2020. "Leaders' Declaration." G20 Leaders' Summit, Riyadh, November 21-22. http://www.g20.utoronto.ca/2020/ G20_Riyadh_Summit_Leaders_Declaration_EN.pdf

Global Carbon Capture and Storage Institute (GCCSI). 2019. "Bioenergy and Carbon Capture and Storage. 2019 Perspective." Melbourne. https://www.globalccsinstitute. com/wp-content/uploads/2019/03/BECCS-Perspective FINAL_PDF.pdf

- - -2020. "CCE Guide: Remove: Carbon Capture and Storage." August. https://www.cceguide.org/guide/ 
Greco, Salvatore, Alessio Ishizaka, Menelaos Tasiou, and Gianpiero Torris. 2019. "On the Methodological Framework of Composite Indices: A Review of the Issues of Weighting, Aggregation, and Robustness." Social Indicators Research 141 (1), 61-94. https://doi. org/10.1007/s11205-017-1832-9

Havercroft, Ian, and Christopher Consoli. 2018. "Is the World Ready for Carbon Capture and Storage? The Carbon Capture and Storage Readiness Index 2018." GCCSI. https://www.globalccsinstitute.com/archive/hub/ publications/202108/ccs-readiness-index-2018globalccs-institute-2018digital.pdf

Heidug, Wolfgang, and Paul Zakkour. 2019. "A Mechanism for CCS in the Post-Paris Era: Piloting Results-Based Finance and Supply Side Policy Under Article 6." KAPSARC Discussion Paper, April. https://doi. org/10.30573/ks--2019-dp52

International Energy Agency (IEA). 2015. "Storing $\mathrm{CO}_{2}$ through Enhanced Oil Recovery." OECD. https://www.iea. org/reports/storing-co2-through-enhanced-oil-recovery

- - - 2020a. "Reuse: Carbon Reuse." G20 Circular Carbon Economy Guide Report. https://www.cceguide. org/wp-content/uploads/2020/08/04-IEA-Reuse.pdf

- - -2020b. "Direct Air Capture." Tracking Report, June. Accessed February 21, 2021. https://www.iea.org/ reports/direct-air-capture

International Energy Forum (IEF). 2020. "The Circular Carbon Economy." IEF Insight Brief, March. https://www. ief.org/programmes/circular-carbon-economy

International Renewable Energy Agency (IRENA). 2019. "Climate Change and Renewable Energy: National Policies and the Role of Communities, Cities and Regions. A report from the IRENA to the G20 Climate Sustainability Working Group." June. https://www.irena. org/-/media/Files/IRENA/Agency/Publication/2019/Jun/ IRENA_G20_climate_sustainability_2019.pdf

Jolliffe, I. T. 2002. Principal Component Analysis. 2nd Edition, Springer Series in Statistics. New York: Springer. https://doi.org/10.1007/b98835

KAPSARC. 2020. "CCE Guide: Overview. A guide to the circular carbon economy (CCE)." https://www.cceguide. org/guide/

King Abdullah University of Science and Technology
(KAUST). 2021. "KAUST Circular Carbon Initiative." Accessed February 20, 2021. https://cci.kaust.edu.sa/

Kirchherr, Julian, Denise Reike, and Marko Hekkert. 2017. "Conceptualizing the circular economy: An analysis of 114 definitions." Resources, Conservation and Recycling 127 (December): 221-32. https://doi. org/10.2139/ssrn.3037579

Lafortune, Guillaume, Grayson Fuller, Jorge Moreno, Guido Schmidt-Traub, Christian Kroll. 2018. "SDG Index and Dashboards: Detailed methodological paper." Bertelsmann Stiftung and the Sustainable Development Solutions Network (SDSN), September. https://raw. githubusercontent.com/sdsna/2018Globallndex/ master/2018GloballndexMethodology.pdf

Mansouri, Noura Y., Alma Alhusseini, Noura T. Al-Saud, Mashael S. Alshalan, Maroua Benlahrech, Yoshikazu Kobayashi, Radia Sedaoui, Masakazu Toyoda, and Liubov Yaroshenko. 2020. "A Carbon Management System of Innovation: Towards a Circular Carbon Economy." Policy Brief. Think-20 (T20) Saudi Arabia. https://www.g20-insights.org/policy_briefs/a-carbonmanagement-system-of-innovation-towards-a-circularcarbon-economy/

McDonough, William. 2016. "Carbon is not the enemy." Nature, no. 539 (November 17): 349-351. https://doi. org/10.1038/539349a

- - - 2020. "Circular Carbon Economy." Webinar by the International Association for Energy Economics, April 9. https://youtu.be/SUqulOIHow4

Melillo, Jerry M., Xiaoliang Lu, David W. Kicklighter, John M. Reilly, Yongxia Cai, and Andrei P. Sokolov. 2015. "Protected areas' role in climate-change mitigation." Ambio (16 October), Royal Swedish Academy of Sciences. https://doi.org/10.1007/s13280-015-0693-1

Organisation for Economic Co-operation and Development (OECD). 2008. Handbook on Constructing Composite Indicators: Methodology and User Guide. OECD and European Commission's JRC. https://doi. org/10.1787/9789264043466-en

Saisana, Michaela, A. Saltelli, and S. Tarantola. 2005. "Uncertainty and sensitivity analysis techniques as tools for the quality assessment of composite indicators." Journal of the Royal Statistical Society: Statistics in Society. Series A 168 (2): 307-23. https://doi. org/10.1111/j.1467-985X.2005.00350.x 
Saudi Aramco. 2020a. "The circular carbon economy." Accessed February 20, 2020. https:// www.aramco.com/en/making-a-difference/planet/ the-circular-carbon-economy

Schröder, Patrick, Siân Bradley, and Glada Lahn. 2020. "G20 Endorses Circular Carbon Economy: But Do We Need It?" Expert Comment, Chatham House, November 27, 2020. https://www.chathamhouse.org/2020/11/ g20-endorses-circular-carbon-economy-do-we-need-it

Sieminski, Adam. 2020. "Circular Carbon Economy." [webinar] International Association for Energy Economics, April 9, 2020. https://youtu.be/SUqulOlHow4

Singh, Harsh Vijay, Roberto Bocca, Pedro Gomez, Steve Dahlke, and Morgan Bazilian. 2019. "The energy transitions index: An analytic framework for understanding the evolving global energy system." Energy Strategy Reviews 26 (2019). https://doi. org/10.1016/j.esr.2019.100382

Socioeconomic Data and Applications Center (SEDAC). 2020. "Environmental Sustainability Index (ESI)."

Columbia University. Accessed December 20, 2020. https://sedac.ciesin.columbia.edu/data/collection/esi

Sustainable Development Solutions Network (SDSN). 2018. "Guidelines for Preparing SDG Indices with SDSN."

United Nations Development Programme (UNDP). 2020. "Human Development Report 2020: The Next Frontier Human Development and the Anthropocene." https://doi. org/10.18356/9789210055161

United Nations Economic Commission for Europe (UNECE). 2019. "Guidelines on Producing Leading, Composite and Sentiment Indicators." https://doi. org/10.18356/3b565260-en

United Nations Environmental Programme (UNEP). 2009. "Environmental Governance."

United Nations Statistics Division (UNSTAT). 2021. "SDG Indicators." Accessed February 20, 2021. https://unstats. un.org/sdgs/indicators/indicators-list/.

Williams, Eric. 2019. "Achieving Climate Goals by Closing the Loop in a Circular Carbon Economy." KAPSARC Instant Insight, November 9. https://www. kapsarc.org/research/publications/achieving-climategoals-by-closing-the-loop-in-a-circular-carbon- economy/\#: :text=Such\%20a\%20closed\%2Dloop $\% 20$ system,and\%20in\%20the $\% 20$ wider $\% 20$ international

- - - 2020. "The Role of Nuclear Power in the Circular Carbon Economy." [webinar presentation] KAPSARC Circular Carbon Economy series, October 26. https:// youtu.be/9Ji3pGILEi8

World Bank. 2020a. "Global Photovoltaic Power Potential by Country." Energy Sector Management Assistance Program. June. https://doi.org/10.1596/34102

- - - 2020b. "Human Capital Project." Accessed May 12 2021. https://www.worldbank.org/en/publication/ human-capital\#Index

- - - 2021a. World Development Indicators database, "Statistical concept and methodology." Accessed January 18, 2021. https://data.worldbank.org/indicator/NV.MNF. TECH.ZS.UN

- - - 2021b. "Logistics Performance Index." Accessed January 28, 2021. https://lpi.worldbank.org/

World Bank/Energy Sector Management Assistance Program (ESMAP). 2020. RISE 2020. Regulatory Indicators for Sustainable Energy. Sustaining the Momentum. Washington D.C.: World Bank. https:// openknowledge.worldbank.org/handle/10986/34937

World Economic Forum (WEF). Fostering Effective Energy Transition. 2020 Edition. Insight report. Geneva: WEF, May 2020. http://www3.weforum.org/docs/WEF_ Fostering_Effective_Energy_Transition_2020_Edition.pdf

World Health Organization (WHO). 2021. "Mortality rate attributed to household and ambient air pollution, age-standardized (per 100,000 population)." Accessed January 29, 2021. https://data.worldbank.org/indicator/ SH.STA.AIRP.P5

Yang, Lin. 2014. "An Inventory of Composite Measures of Human Progress." Occasional Paper on Methodology. UNDP - Human Development Report Office. http://hdr.undp.org/en/content/ inventory-composite-measures-human-progress

Yilmaz, Fatih. 2021. "Understanding the Dynamics of RE transition: A Determinant Index Approach." KAPSARC Methodology Paper (forthcoming). 


\section{Notes}

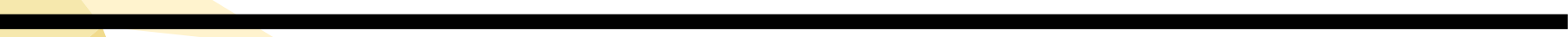




\section{About the Authors}

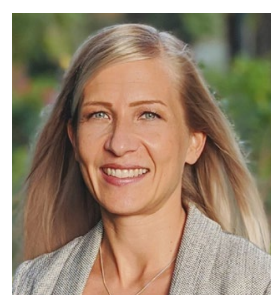

\section{Mari Luomi}

Mari is a policy-oriented social scientist who has been studying climate change, energy transitions and sustainable development policy in the Gulf and globally for close to 15 years. She has worked for other leading energy, sustainable development and foreign policy research institutions, including the Oxford Institute for Energy Studies, the International Institute for Sustainable Development (Earth Negotiations Bulletin), Georgetown University, the Finnish Institute of International Affairs, and the Emirates Diplomatic Academy.

Mari holds a master's degree in political science and international politics from the University of Helsinki and a Ph.D. in Middle Eastern Studies from Durham University.

In addition to a broad research publications portfolio, she has substantial experience in executive training, presentations, policy advisory, and reporting services for multilateral environmental negotiations.

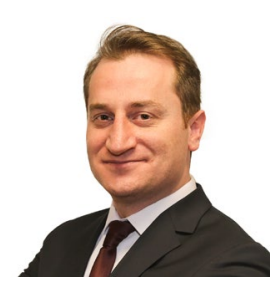

\section{Fatih Yilmaz}

Fatih is a senior research associate in the Energy Transitions and Electric Power program. His current research agenda aims to enhance our understanding of the financial and economic consequences of the global energy transition toward renewables, and to design effective policies to balance financial risks and growth prospects.

Before joining KAPSARC, Fatih worked as an economist in the Structural Economic Research Department of the Central Bank of the Republic of Turkey, where he was involved in the research and the design of policies for the private and banking sectors. He has also worked as a consultant for the World Bank, where he took responsibilities in various consulting projects for the Canadian and Turkish Governments. Fatih spent a year as an assistant professor at the ADA University , Azerbaijan, and worked as a graduate assistant at the University of Calgary and at the Western Illinois University, where he taught several courses in economics and econometrics.

Fatih has authored various academic and policy articles and book chapters. He has helped organize conferences and workshops, and has acted as a referee for many academic journals. 


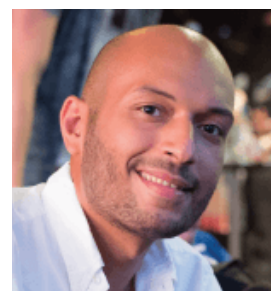

\section{Thamir Alshehri}

Thamir is a research associate in the Energy Transitions and Electric Power program. He is currently focused on creating data-driven tools to identify and evaluate different energy market scenarios, as well as using 'big data' technologies to better understand the impact of consumer behavior and the environment on energy consumption. Thamir is interested in using technologies to facilitate better energy public policy and energy economical systems.

Thamir also acts as an advisor to the broader energy ecosystem in Saudi Arabia, particularly in the areas of clean energy transitions, sustainability, and carbon emissions management. He is also a member of the Technology and Economic Assessment Panel, United Nations Environment Programme (UNEP).

He previously worked as a lecturer in Australia and has entrepreneurial and industrial experience from working on award-winning projects such as the Burj Khalifah Building Management System.

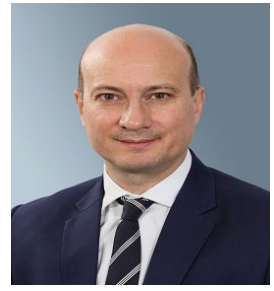

\section{Nicholas Howarth}

Nicholas is a former research fellow at KAPSARC and an applied economist specializing in energy, technological change and climate change. He obtained his D.Phil. in Economic Geography and M.Sc. in Environmental Change and Management from the University of Oxford and has a Bachelor of Economics with honors from the University of Adelaide, South Australia. 


\section{About the Project}

The Circular Carbon Economy (CCE) Index project seeks to expand and add rigor to the conceptual basis of CCE by developing a robust quantitative framework to measure country performance and progress toward CCEs. The CCE Index project, which will run through 2021, consists of various components, including a KAPSARC Methodology Paper published in spring 2021 that provides a conceptual-methodological framework for the CCE Index and for related expert and stakeholder consultations. The results of the first edition of the CCE Index, aimed to be finalized in time for the 2021 UN Climate Change Conference, will be published in a report containing the results for a selected group of countries, such as the Group of Twenty (G20) and several hydrocarbon exporting countries. A web-based dashboard is also planned for easier visualization of the results, along with other web-based tools.

The CCE Index is a composite indicator measuring various dimensions of the CCE in a national context across countries. For each country, it provides a snapshot of data based on the latest available year and shows indicator-based trends over a period of years.

The CCE Index has two main aims: first, it is intended as a vehicle to promote the concept of the CCE and the idea of adopting a holistic approach to managing emissions across energy systems and economies. Second, the Index is intended to enable further discussions around ways to identify, measure and compare countries' strengths and weaknesses in terms of the CCE, and to help pinpoint areas where progress is already well underway and where further policy efforts are needed.

The CCE Index, and related stakeholder consultations, are also intended to support discussions within Saudi Arabia on ways to promote and advance the CCE, including by providing inputs into and drawing from work on the CCE National Program announced in November 2020 by HRH King Salman bin Abdulaziz Al Saud. The project's audience and stakeholders comprise domestic and international energy and climate change actors in government, the private sector, international organizations, research institutions and civil society.

The publication of this paper is accompanied by a list of suggested indicators and related data points for the G20 countries and selected oil-producing countries. They will be made available to domestic and international experts and other stakeholders in spring 2021. Together with the Methodology Paper, it will serve as the basis for soliciting comments and suggestions to help refine the CCE Index prior to its finalization later in 2021. 
INAPSARC

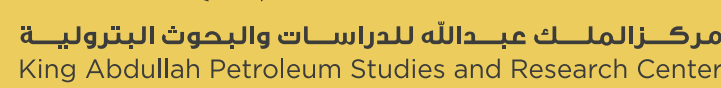

www.kapsarc.org 